\title{
OMA mulls legal action over new cuts
}

$\mathrm{T}$ he Ontario Medical Association (OMA) is considering legal action if the province won't return to the bargaining table with a new, impartial process for settling disputes over physician pay.

In October, the Ontario government plans to impose another $1.3 \%$ cut to all fees paid to doctors. This follows January's $2.65 \%$ cut to doctors' fees and other unilateral reductions in funding for continuing medical education, walk-in clinic visits, doctors who enrol healthy patients in their practices and family health teams in well-serviced areas.

OMA President Dr. Mike Toth says the province owes doctors a "fair, reasonable negotiation done in good faith." This ought to include an impartial, binding process for resolving an impasse between the parties, he adds. "There's a power imbalance if the government can go through a series of negotiations and still have the right to unilateral action without any recourse."

OMA wants negotiations to go through a form of mediation-arbitration that would give a neutral third party the power to issue a binding decision in cases where the province and doctors can't agree. Failing that, "we're also looking at our legal options," Toth says.

Eight of the provinces and territories currently have a binding dispute resolution mechanism, although they may not often use it, he explains. The Canadian Medical Association also gave its support to OMA's request for mediationarbitration at its August General Council meeting in Halifax.

Normally, the national doctors' association doesn't get involved in provincial pay disputes, but in this case there could be national implications. According to Steven Barrett, a constitutional lawyer with Sack Goldblatt Mitchell in Toronto, if physicians feel there isn't a fair process for determining their compensation within Medicare, they may be more willing to advocate for their right to practise and bill outside the public system.



The Ontario Medical Association may take Queen's Park to court over unilateral pay cuts.

Negotiations between doctors and the Ontario government have stalled since January, after the OMA rejected a proposal to cap growth in the physician services budget at $1.25 \%$. Ontario ended up imposing the cap anyway, despite the fact that its own estimates peg the current rate of growth in demand for medical services at $2.7 \%$. This means doctors won't be reimbursed if patient demand for their services exceeds the limits of the public purse.

The province hasn't given the OMA current data on health care use, but it's "probably a safe bet to say it's running over budget," says Toth.

Stephen Skyvington, a former manager of government relations for the OMA, recently reported that Ontario is withholding the data to prevent doctors from slowing their work in protest of pending claw backs.

David Jensen, a spokesperson for the Ministry of Health and Long-term Care, denies that this is the case. "The ministry continues to share data with the OMA per our data sharing agreement." Jensen neither confirmed nor denied reports that spending on physician services is running $10 \%-20 \%$ over budget.
In theory, doctors can protest pay cuts through work slowdowns and strikes, but it's often not politically or ethically feasible because of the essential nature of their services. Nevertheless, "we're obviously looking at all of our options right now," says Toth.

The OMA successfully brought Ontario back to the bargaining table in 2012 by launching a constitutional challenge to unilateral cuts imposed by the government of the day. Ultimately the parties resolved their differences out of court, producing fee agreements for fiscal years 2012/13 and 2013/14. At the same time, the OMA agreed to the current negotiating framework, in which the government may act unilaterally if an impasse remains after receiving help from a facilitator and advice from a conciliator. "During the latest round of negotiations, this process was followed," explains Jensen, for the ministry.

A binding dispute resolution process "wasn't on the table" in 2012, says Toth. "We couldn't get to it at that time but we think we can get to it now." Lauren Vogel, CMAJ

CMAJ 2015. DOI:10.1503/cmaj.109-5159 